\title{
Social representations formulated by high school students
}

\author{
Representações sociais sobre aprendizagem \\ formuladas por adolescentes \\ do ensino médio
}

\author{
Wilma Nascimento dos Santos Ganso CARVALHO \\ Márcia Siqueira de ANDRADE
}

\begin{abstract}
The aim of this research is to identify and analyze the social representations of learning formulated by adolescents. In order to do so, three descriptive case studies were carried out using transversal methodology with High School students from three schools. For data collection, a semi-structured questionnaire was used. Two forms of analysis were performed at a later stage: the qualitative data was analyzed by the technician of Content Analysis; the quantitative data was submitted to descriptive and inferential analysis. A posteriore, three theoretical categories that emerged from the discourse used by the participants pointing to different social representations about learning traditional, renewed and contemporary conceptions. The results show the predominance of the contemporary concept among the studied groups. This scenario suggests that the adolescents who assumed the contemporaneous concept represent the learning connected to the peripheral system, a device that prepares crystallized transformations, diminishing the confrontation between subjective reality and consensual elements, which are part of the central core of social representations.
\end{abstract}

Uniterms: Adolescent; Learning; Social perception.

\section{Resumo}

O objetivo desta pesquisa é identificar as representações sociais sobre aprendizagem formuladas por adolescentes. Para se alcançar o objetivo proposto, realizou-se estudo de caso descritivo de caráter transversal com alunos do ensino médio de três escolas. Para a coleta de dados, foi aplicado questionário semiestruturado. Os dados qualitativos foram analisados pela técnica da análise de conteúdo, eos dados quantitativos, por análises descritivas einferenciais. Foram levantadas, a posteriore, três categorias teóricas que emergiram dos discursos dos participantes, o que indica distintas representaçôes sociais sobre aprendizagem: concepção tradicional, renovada e contemporânea. Os resultados apontam a predominância da concepção contemporânea nos grupos estudados. Essa situação sugere que os adolescentes que assumiram a concepção contemporânea representem a aprendizagem de forma vinculada ao sistema periférico, dispositivo que prepara as transformações cristalizadas, amortecendo o confronto entre realidade subjetiva e elementos consensuais, constitutivos do núcleo central das representações sociais.

Unitermos: Adolescente; Aprendizagem; Percepções sociais.

\footnotetext{
viv

1 Centro Universitário Fundação Instituto de Ensino para Osasco, Programa de Psicologia Educacional. Av. Franz Voegeli, 300, Campus Vila Yara, Bloco Prata, 06020-190, Osasco, SP, Brasil. Correspondence to/Correspondência para: M.S. ANDRADE. E-mail: <mandrade@unifieo.br>.
} 
This research aimed at identifying and analyzing the social representations about learning formulated by teenagers in High School. Considering a scenario where the capacity to learn is shown to have become essential in any area, this research had as a main questioning what a teenager nowadays thinks about learning. Studies in the area justify the relevance of the matter.

Pozo et al. (2006) consider contemporary society a society of lifelong learning, where learning is no longer limited only to the times and spaces of formal education, but is part of all life and all living spaces that human beings inhabit. This situation points to the need of learning to learn, which allows each individual to organize and manage their own learning process.

Contemporary society requires humans to have self-regulated, conscious learning, enabling guidance before the vast amount of information available through a clear understanding supported by solid and well-sustained criteria (Pozo et al., 2006). From this point of view, "learning involves reconstructive mental processes of its own representations of the physical world, including sociocultural and mental, as well as self-regulation of the learning activity itself" (Pozo et al., 2006, p.124).

In this research, we adopted the definition of adolescence according to Moreira (2000), to whom the concept of adolescence should not be taken as natural and universal. It is a category historically formed and operated by social, cultural, political and economical forces. Adolescence represents the beginning of youth, featuring a time of changes in the body, in the emotions and in social and relational references, changes that will remain present, somehow, throughout life.

Putting the adolescent as research focus is justified, in part, in view of the results of the latest census of the Instituto Brasileiro de Geografia e Estatistica (IBGE - 2003): in 2000 the population was made up of approximately 175 million people, 35 million of which corresponded to the age group between 13 and 19 years (adolescents), that is $21.84 \%$ of the total population of the country.

Data on the education of adolescents, however, is worrisome: their school enrollment index, considering the population between 15 and 17 years old, does not exceed 25\%, which places Brazil in a situation of inequality in relation to many countries, including other countries in America Latina (Brasil, 1997, p.6).

\section{Social representations}

Social representations, according to the classical definition presented by Jodelet (1985), are modalities of practical knowledge oriented for communication and the understanding of social, material and ideal context in which one lives. They are forms of knowledge that manifest themselves as cognitive elements, images, concepts, categories and theories, but that cannot be reduced to cognitive components. Being socially elaborated and shared, they contribute to the construction of a common reality, which allows communication.

Thus, representations are essentially social phenomena that, even when accessed from their cognitive content, must be understood from the context of their production, that is, from the ideological and symbolic functions they serve and forms of communication around them. Social representations enable the study of the complex relationships between individuals and society, considering the cognitive and affective dimensions, besides the social one.

Social representations are also an expression of intraindividual reality, an externalization of affection. According to Jodelet (1989, p.41),"social representations must be studied articulating affective, mental and social elements, integrating cognition, language and communication to the social relations that affect social representations and the material, social and ideal reality with which they are involved."

Moscovici (2003) describes two mechanisms in the formation of social representations: anchoring and objectification. The first seeks anchor strange ideas and concepts, putting them in a familiar context, while the second, by objectifying an idea, transforms the "strange and abstract" in concrete, which relates a thought to something existing and tangible. In the process of anchoring, there is the cognitive integration of the represented object, as anchoring means classifying, naming, categorizing and labeling. In the process of objectification, there is the transformation of a concept; objectifying means reproducing what was verbally thought in an image. 
According to Abric (2001), every representation is organized around a central core, which determines the meaning and organization of the representation. According to Abric (1997), a representation consists of a set of information, beliefs, opinions and attitudes regarding a given social object. This information is organized around a structure, which is a specific sociocognitive system, that is those contents are structured in the representation of elements in a hierarchical core. Around this core, peripheral elements are organized.

The core has two functions: 1) the generating function: from the central core, the meanings of the other elements of the representation are created or transformed; 2) the organizing function: it determines the nature of the conjunction among the elements of representation, being, therefore, unifying and stabilizing . The peripheral elements are organized around the core elements and are more concrete, accessible and alive (Abric, 1997).

The central elements of the representation are determined by the nature of the represented object and by the relationship that the subject has with that object. These are very stable elements of representation, from which the meaning of other constituting elements of representation can be created or transformed. These central elements also determine the nature of the connections that relate them to each other.

The core is connected and determined by historical, sociological and ideological conditions and it is marked by collective memory and the system of norms. It evolves slowly. The core is responsible for attributing and transforming meaning (value) to the represented object; it assures the permanence or perennial of the representation; it allows one to understand reality; it gives uniformity to the group and defines the fundamental principles around which the representations are constituted; it is simple, concrete, consensual, historically marked, imagistic and coherent; it has a symbolic value. It cannot be rebuttable (Moliner, 1995).

Later on, Flament adds to this proposition the idea of peripheral elements (Moliner, 1995), since these elements, taken as circumstantial and accessory in relation to core elements, were probably excluded from researchers' preoccupations. Flament (2001) assigns the function of prescribing behaviors to peripheral elements, leading the individual to act spontaneously in a given context.

The peripheral elements, consisting of a greater number of ideas on the represented object, make the interface between the core and the concrete situations and practices of the population, incorporating the experiences and individual stories of their members, thus showing itself as being not only more sensitive to the influence of the immediate social context, but also more flexible in the orientation of the behaviors happening in such context (Abric, 1997).

Abric (1997) outlines five functions of anchoring, or the peripheral system, in the functioning and dynamics of representations:

a) The embodiment of the core in terms anchored in reality, immediately understandable and communicable;

b) The regulation, which consists in adapting the representation to changea in the context, incorporating new elements or modifying others depending on concrete situations in which the group is confronted;

c) Prescribing behavior: the elements of the peripheral system function as schemes organized by the core, ensuring the instant operation of the representation with a reading grid of the given situation, thereby orienting taking positions;

d) The protection of the core: the peripheral system is an essential element for defense mechanisms that aim to protect the central meaning of the representation;

e) The individualized modulations: this is the peripheral system that allows the elaboration of representations related to history and personal experiences.

To Abric (2002), the peripheral system is richer and more complex than the central system. This author supports that relationships between the representations and practice can be examined from the study of peripheral elements and that understanding the central system would allow us to figure out obvious things that are already known. However, most scholars of social representations theory do not share this idea. The peripheral system, unlike the central system, is determined by the central core, to which it is linked, and establishes an interface between this and the concrete 
reality, in which the representation works. It is the most accessible, flexible, adaptive, living and concrete part of the representation.

In this light, it can be concluded that the theory of social representations allows us to understand the meaning that adolescents attribute to learning. Through representations, we become aware of the ways teens establish relationships with their teachers, parents and other members of society to which they belong; we also become aware of the influence of these relationships in the educational process. Once the practices are carried out in accordance with the representations of teenagers, it becomes possible to identify, through the discourse of these actors, the conceptions and actions that affect, positively or negatively, the results of their learning.

\section{Method}

In order to achieve the objective proposed, there were three case studies of descriptive transversal character: 1) with students from a private school located in a middle-class neighborhood (Escola Particular 1-EP1); 2) with students from a private school located in a highclass neighborhood (Escola Particular 2 - EP2); 3) with students from public school located in a poor neighborhood on the outskirts of town (Escola Pública-EPU). The three schools that serve the participants in this study are located in the western region the city of São Paulo.

\section{Research field}

The first school that served as a field for data collection, the EPu, is located in a poor neighborhood close to three slums, on the outskirts of the city, a region with many churches, mostly Gospel, that lacks resources and leisure opportunities. Students attending this school come from, mostly, these three slums. The school belongs to the State public system, serves 1,500 high school students and holds morning, afternoon and evening classes.

The second school, EP1, located in a a middleclass neighborhood, belongs to the private network and offers kindergarten, elementary and high school, serving 500 students. It is located in a tree lined area, with parks and squares, it is near the University of São Paulo (Universidade de São Paulo) and the Instituto Butantan, institutions offering free cultural programs, attended by students and their families.

The second school of the private Education System, EP2, offers only high school and professionalizing education to 250 students. Students of this school belong to families with high purchasing power, have access to all media and culture, travel frequently and are members of the most exclusive clubs in São Paulo. The students have had problems in other schools and try, at EP2, to finish high school. This is a school with a differentiated pedagogical proposal that tries to understand students' difficulties in order to try to help them overcome them.

\section{Participants}

Eighty two adolescents of both sexes, High School students, aged between 15 and 19 years, participated in this study and were divided into three groups: GEP1, composed of 10 students from Private School 1 (EP1); GEP2, composed of 54 students from Private School 2 (EP2), and GEPu, composed of 18 students from a State Public School (EPu). All participants were selected through a random sample of convenience. The inclusion criterion was to be a teenager, a high school student, to take part in the research and present the term of consent duly signed.

The data also shows that while only $9.26 \%$ of adolescents are 19 years old, this is a balanced sample in terms of gender and age.

\section{Instruments}

In order to collect data a semi-structured questionnaire with closed and open questions was applied. The script of the questionnaire contained objective data (gender, age, education) and subjective data regarding attitudes, values, opinions and feelings peculiar to the learning experiences of the interviewed participants (Minayo, 1996). These were the questions: a) What is learning for you?; b) Where do you learn?; c) What do you learn?; d) Who do you learn from?; e) Who will you teach what you have learned?

The students were asked that, for each answer, the first three words associated to the question that came to mind were listed. 


\section{Procedures}

The project was approved by the Research Ethics Committee of the promoting institution. We requested a declaration for the research, and we were given the authorization for its implementation in the three schools.

Observing the Resolution 196/96 from the National Health Council, a letter informing the participants and their parents was issued in order to inform about the theme and purpose of the study, ensuring that the information would be treated confidentially and anonymously and serve only for technical-scientific purposes. Participants and / or their guardians signed a consent form.

The data were collected in schools EP1 and EP2 by the researcher, who went to the classrooms of high school during classes, explained the research proposal and invited the students to participate. At the school EPU, data was collected by the Portuguese teacher, who offered to do it as the direction of the school did not allow the researcher responsible did so.

\section{Results and Discussion}

In order to analyze the material relevant to this research we described and related demographic data and the themes addressed in the questionnaire. For this, there were two forms of analysis: content analysis for the qualitative data, and descriptive and inferential analysis, for quantitative data.

The responses collected were analyzed using the words that emerged from questions posed in a lexicographical perspective, that is, considering the frequency and order of the recalling of words. The words evoked were then grouped into semantically close categories and analyzed in the light of conceptions of teaching / learning present in the texts that make up the National Curriculum (Brasil, 1997), as these are the documents that regulate the teaching/learning process in the country.

The two words that appeared first in each response by at least $50 \%$ of the questionnaires were considered as part of the core. The others were considered as part of the peripheral core.
Following the orientation of Tura (1998), in order to make the analysis more consistent and representative, words evoked once or twice were discarded.

Three theoretical categories were created $a$ posteriore from the discourse of the participants, indicating distinct social representations on learning: one of them linked to what is called the traditional view, the second one linked to a renewed conception of learning, and a third denominated as the contemporary learning conception. These distinct representations bring in their core different philosophical conceptions of man and the world, and each one of them shows a way of seeing the world and interacting with it.

\section{Traditional conception}

The traditional concept arises, in teenagers' discourse, directly related to the teaching indicator and to two different spaces: school and family. Thus, both teachers and parents are regarded as capable of teaching. The contents taught are linked to traditional teaching contents, such as math, grammar and historical facts. Table 1 shows the frequency and the percentage in which this conception is present in each of the groups studied.

The EP1 and EP2 are the two groups that have been referred to, respectively, with the lowest (100.00\%) and highest presence (20.68\%) of the teaching indicator, suggesting a traditional teacher-centered conception of learning.

For these teenagers, learning means acquiring knowledge passed on by someone else, mindlessly delegating to parents and / or teachers the responsibility for their learning. Learning, in this view, takes place without creativity and initiative.

The contents taught by parents and / or teachers, in these adolescents' point of view, correspond to

\section{Table 1}

Frequency and percentage of the traditional conception. Osasco (SP), 2010

\begin{tabular}{lcc}
\hline Group & Frequency & Percentage \\
\hline EP1 & 0 & 0.00 \\
EP2 & 12 & 20.68 \\
EPu & 1 & 5.55 \\
\hline
\end{tabular}

Note: EP1: Private School 1; EP2: Private School 2; EPu: Public School. 
knowledge and social values accumulated by past generations as unquestionable truths, not necessarily related to real problems that affect society.

According to the National Curriculum Parameters (Brasil, 1997), for the traditional conception, the relationship between learners and teachers supersedes the authority of the one who teaches, which requires a receptive attitude from adolescents and impairs communication between teacher and student. This relationship with knowledge defines a conception of learning as an exact and unequivocal reproduction of reality.

This is an empirical conception, according to which knowledge if found ready in the external world, waiting to be learned by the individual. Teaching is reduced to the transmission of knowledge and learning, to the absorption of the content being passed on.

\section{Renewed conception}

The renewed conception can be identified in the discourse of teenagers through the following indicators: "learning," "things I learn", "the way we learn". Although these indicators relate learning to school, they also consider broader spaces, such as the Internet, newspapers, the world. In this perspective, the content learned also expands itself. These teenagers consider what they learn "things of life", "useful things", "several things".

Table 2 indicates the frequency and the percentage in which this conception is present in each of the groups studied.

The renewed conception is more frequently present in the public school (33.33\%). It is understood as a renewed conception, as opposed to the traditional conception, the one that places the student in the center

\section{Table 2}

Frequency and percentage of the renewed conception. Osasco (SP), 2010

\begin{tabular}{lcc}
\hline Group & Frequency & Percentage \\
\hline EP1 & 3 & 30.00 \\
EP2 & 12 & 20.68 \\
EPu & 6 & 33.33 \\
\hline
\end{tabular}

Note: EP1: Private School 1; EP2: Private School 2; EPu: Public School. of the learning process and places the mere transmission of content by the teacher in a secondary position.

According to Luckesi (1994), the renewed conception includes several lines of thought that, in a way or another, are related to the movement of nondirective pedagogy, represented mainly by psychologist Carl Rogers and by the movement called New School or Active School.

These lines of thinking, although they admit differences, take the same guiding principle valuing the individual as a free, active and social being. The center of activity is not the schoolteacher or the subject content, but rather the student, as an active and curious being. The most important thing is not the teaching itself, but the learning process. "It is about 'learning to learn, that is, the process of knowledge acquisition is more important than knowledge itself "(Luckesi, 1994, p.58).

The one who teaches facilitates the free and spontaneous development of the individual, the process of searching for knowledge, which should come from the individual who is learning. It is up to the one teaching to organize and coordinate the learning situations, adapting their actions to the individual characteristics of the one learning, in order to help these develop their own capacities and intellectual abilities. The teacher stimulates to the maximum the motivation of the individual who is learning, awakening in them the search for knowledge, the reaching of personal goals as well as learning goals, and the development of competences and skills. Thus, the teaching process is designed to provide a favorable environment leading to selfdevelopment and appreciation of "myself".

According to Luzuriaga (1980, p.227): "by new education we mean the line of thinking that deals with changing the course of traditional education, which is intellectualist and bookish, giving it the sense of something that is alive and active. This is why this movement has also been given the name of Active School:

Regarding aesthetical theories and practices, the pedagogy of the New School breaks with "copies of models" and promotes creativity and free expression. 
The modern aesthetics favors inspiration and sensitivity, emphasizing respect for the individuality of the student.

This tendency had large penetration in Brazil in the 1930s, especially in pre-school (kindergarten). Even today, this current influences some teaching practices, most notably in early childhood education, especially in the field of educational guidance and school psychology.

\section{Contemporary conception}

The contemporary conception appears in $50.00 \%$ (24) of the answers related to the knowledge indicator in $20.83 \%$ (10 responses) related to the information indicator. Most teenagers cannot relate learning to a certain space and claim to learn "everywhere", "in life", in "everyday routine". Likewise, they demonstrate difficulties identifying the object of learning, defining it with uncertain and vague expressions, such as:"things I will use in life", "living in society", "everything", "new things". Similarly, they do not clearly identify whom they learn from:"from everybody","from people around", "from those who have something to teach". We also see here the media in the place of the people who teach:" $t v$, newspapers, the Internet, books".

Table 3 shows the frequency and the percentage of the presence of the contemporary conception of learning in teenagers' discourse.

The contemporary conception is more frequently present in the discourse of adolescents from the three schools. The contemporary conception can be understood as one turned to a new way of relating to knowledge, connected to what Pozo (2002) denominates as "the learning society". The learning society is mainly characterized by the idea of learning in a non-nuclear way. The symbolic culture of the learning society implies

\section{Table 3}

Frequency and percentage of the contemporary conception. Osasco (SP), 2010

\begin{tabular}{lcc}
\hline Group & Frequency & Percentage \\
\hline EP1 & 7 & 70.00 \\
EP2 & 30 & 55.55 \\
EPu & 11 & 61.10 \\
\hline
\end{tabular}

Note: EP1: Private School 1; EP2: Private School 2; EPu: Public School. new ways of learning resulting from the presence of vast possibilities of control, storage and access liberation of multiple information sets. In this society, humanity leaves its original bases originated, firstly from agriculture and later to manufacturing and industry, to go onboard the economy of learning, in which the manipulation of information is the main activity. The economies of leaning are stimulated and moved by creativity and interactivity.

According to Pozo et al., (2006), the contemporary conception of learning"can already exist in several spaces of social management of knowledge - outside the classrooms - and demand new proposals from educational systems" (Pozo et al. 2006, p.51). For Pozo, schools still resist to these new ways to conceive learning.

The contemporary conception presupposes spaces that are not dedicated either to provide information to the learner, but to convert the information they already have in true knowledge (Pozo, 2003). The contemporary conception understands learning not as a process resulting from direct transmission of established knowledge, but as a dialogue with a more uncertain form of knowledge. It also assumes that the contents to be learned, given its largely relative and transitory character, should not be an end in themselves but a necessary and not arbitrary means to promote certain capacities in the learner (Pozo \& Postigo, 2000).

Table 4 shows the percentage of occurrence of each of the three concepts of learning groups considered in this study.

Schools that served as a field for research declare adopting a pedagogical paradigm founded on interactionism, here called Renewed, in which learning is understood as a procedural construction and reciprocal human interaction with the object of knowledge, and one who teaches is perceived as a mediator of this process.

\section{Table 4}

Percentage of conceptions of each group. Osasco (SP), 2010

\begin{tabular}{lrrr}
\hline & Tradicional & Renewed & Contemporary \\
\cline { 2 - 3 } \cline { 4 - 4 } Group & & 30.00 & \\
\hline EP1 & 0.00 & 20.68 & 70.00 \\
EP2 & 20.68 & 33.33 & 65.55 \\
EPu & 5.55 & 61.11 \\
\hline
\end{tabular}

Note: EP1: Private School 1; EP2: Private School 2; EPu: Public School. 
Therefore, and considering the responses of adolescents, the elements belonging to the central core are those that appear less frequently and prompt recall in the three groups. They represent reality crystallized in beliefs, marked by collective memory and the system standards.

However, there is a predominance of contemporary design in the groups studied. This situation suggests that teens who took the contemporary conception represent learning so bound predominantly to the peripheral system (Abric, 2003), serving as a "bumper from a reality that challenges a central core and that should not change easily" (Flament, 2001, p.178). It is the peripheral system that prepares the transformation of social representations by activation of peripheral schemes.

This statement points out that, to be protected and the core to be ensured the stability of a social representation in its periphery there verbalizations more subjective and less frequently uttered by the groups surveyed about learning, and, therefore, absorbed by schemes peripherals. Thus, the system peripheral device serves to cushion the clash between subjective reality and the consensus, constituting the core of social representations.

Having regard to the functions of the peripheral system, a social representation of learning was found that can adapt to the various changes that a changing society subject those who compose it.

\section{Final Considerations}

This research sought to identify and analyze the social representations made by teenagers learning about High School students.

Three theoretical categories that emerged from the speeches of the participants, were identified and analyzed, which indicates distinct social representations of learning: one linked to what is called traditional design, another linked to a renewed conception of learning and the third called contemporary conception of learning. These distinct representations bring in thier wake, different philosophical conceptions of man and the world, and each one of them shows a way of thinking about the world and act on it.
Although the epistemological beliefs are not really personal conceptions about learning, how one conceives the nature of knowledge affects the kind of processes and strategies employed to learn. Thus, this research represents a contribution to the body of research that present data on the adolescent population and their education.

Accordingly, the results suggest the need for further studies on the subject, so to understand how these representations affect the academic performance of adolescents, since social representations indicate the direction of the action.

\section{References}

Abric, J. C. (1997). Les représentations sociales: aspects théoriques. In J. C. Abric (Org.), Pratiques sociales et représentations (pp.11-37). Paris: Presses Universitaires de France.

Abric, J. C. (2001). O estudo experimental das representações sociais. In D. Jodelet (Org.), As representações sociais (pp.155-171). Rio de Janeiro: UERJ.

Abric, J. C. (2002). L'approche structurale des représentations sociales: développements récents. Psychologie et Société, 2 (4), 81-103.

Abric, J. C. (2003). Méthodes d'études des représentations sociales. Ramonville Saint-Agne: Edition Eres.

Brasil. Ministério da Educação e Cultura. (1997). A tradição pedagógica brasileira. In Ministério da Educação e Cultura (Org.), Parâmetros curriculares nacionais (pp.6-33). Brasília: MEC.

Flament, C. (2001). Estrutura e dinâmica das representações sociais. In D. Jodelet (Org.), As representações sociais (pp.173-186). Rio de Janeiro: UERJ.

Instituto Brasileiro de Geografia e Estatística. (2003). Pesquisa nacional por amostra de domicílios 2000 [CD-ROM]. Microdados. Rio de Janeiro: Autor.

Jodelet, D. (1985). La representación social: fenómenos, concepto y teoria. In S. Moscovici (Org.), Psicologia social (pp.469-494). Buenos Aires: Paidós.

Jodelet, D. (1989). Représentations sociales: un domaine en expansion. In D. Jodelet (Org.), Les représentations sociales (pp.31-61). Paris: PUF.

Luckesi, C. C. (1994). Filosofia da educação. São Paulo: Cortez.

Luzuriaga, L. (1980). História da educação e da pedagogia. São Paulo: Editora Nacional.

Minayo, M. C. S. (1996). Pesquisa social: teoria, método e criatividade. Rio de janeiro: Vozes.

Moliner, P. (1995). A two-dimensional model of social representations. European Journal of Social Psychology, 25(1), 27-40 
Moreira, M. I. C. (2000). Psicologia da adolescência: contribuições para um estado da arte. Interações: Estudo e Pesquisas em Psicologia, 5(10), 25-51.

Moscovici, S. (2003). Representações sociais: investigações em psicologia social. Rio de Janeiro: Vozes.

Pozo, J. I. (2002). Aprendizes e mestres. Porto Alegre: Artmed.

Pozo, J. I. (2003). Adquisición de conocimiento: cuando la carne se hace verbo. Madrid: Morata.

Pozo, J., \& Postigo, Y. (2000). Los procedimientos como contenidos escolares: uso estratégico de la información. Barcelona: Edebé.
Pozo, J. I., Scheuer, N., Pérez, M., Mateos, M., Martin, E., \& Cruz, M. (2006). Nuevas formas de pensar la enseñanza y el aprendizaje: las concepciones de profesores y alumnos. Barcelona: Editorial Grao.

Tura, L. F. R. (1998). Aids e estudantes: a estrutura das representações. In D. Jodelet \& M. Madeira (Orgs.), Aids e representações sociais: a busca de sentidos (pp.121-154). Natal: EDUFRN.

Received on: 23/11/2010

Final version on: 12/4/2012

Approved on: 28/5/2012 
